\title{
Responding to the challenge of father absence and fatherlessness in the South African context: A case study involving concerned fathers from the North West Province
}

\author{
Freeks, Fazel \\ North-West University \\ 10589686@nwu.ac.za
}

\begin{abstract}
This article is about the challenge of father absence and fatherlessness in the South African context, and the involving of concerned fathers. To address this challenge, an intervention was crucial as well as the training and equipping of fathers. This intervention consists of different fathers from the North West Province who responded to the challenge of father absence and fatherlessness after workshops presented in a narrative form. The workshops were based on research on fatherhood as this is conceptualized from a Biblical perspective. The research ${ }^{1}$ is necessary because South Africa experiences a challenge of absent fathers and fatherlessness. This research ${ }^{2}$ showed that the greatest problem with regard to fatherhood is centred on a man's failure to resolve an identity crisis in the $21^{\text {st }}$ century, but men are generally afraid to admit it. This problem has consequences for families and communities. Furthermore, this article reports on the responses and feedback of fathers and the supporting of literature in the research.
\end{abstract}

Key words

Father absence; fatherlessness; intervention; programme; role of the father

1 Freeks, 2011 - The role of the father as mentor in the transmission of values: A Pastoraltheological study

2 Freeks (2011:1-7) 


\section{Introduction}

In the last few decades, the South African society has strayed away from recognizing the importance that fatherhood holds (Ratele et al., 2012; Freeks 2004; Krohn \& Bogan 2001). In many cases the family has been redefined, and the father is not even present (Ford et al., 2008). Children obviously need their fathers and want to spend time with them, as Willerton et al. (2011) and Freeks (2011) indicated it. Children want the father's presence and not the father's presents. The traditional family is fading away, and with it we are losing God's idea in terms of family, and the significant role of the father (cf. Freeks 2016:13-20; Freeks 2011:204-212; Le Roux 2007; Bergh 2002:47-55). Most South African communities are facing the challenge of father absence. A possible solution to the challenge could be the restoration of fathers with the focus on their crucial role within families (Del Russo 2009).

\section{Problem statement}

Father absence and fatherlessness is a worldwide phenomenon and a worldwide tendency in communities (Freeks 2013:3; Freeks 2016). Research was done in twenty one countries of the world i.e. America, Russia, South Africa, Brazil, Grenada, Seychelles, Chattanouga, and others, and in every country, father absence and fatherlessness was identified as the biggest problem (Carstens 2014:9-11; cf. also Richter et al. 2012, Freeks et al. 2015:22-24; Freeks 2013:8-18; Freeks 2011:1-4; Freeks \& Lotter 2009:520524; Freeks 2004:1-6). The following statistics caused havoc in terms of family and societies in America:

- $63 \%$ of suicides come from fatherless homes,

- $70 \%$ of juveniles in state operated institutions come from fatherless homes,

- $80 \%$ of rapists motivated by displaced anger come from fatherless homes,

- $40 \%$ of all children do not live with their biological fathers,

- $85 \%$ of children with behavioural problems come from fatherless homes,

- $90 \%$ of homeless children come from fatherless homes, 
- $71 \%$ of children who do not finish school come from fatherless homes (Carsten 2014; Fathers for life 2013; Statistics South Africa 2011; Goodsell \& Meldrum 2010).

Further, the following statistics indicated a great concern in communities in America, regarding men:

- Men commit $90 \%$ of major crimes.

- Men commit $100 \%$ of rapes.

- Men commit $95 \%$ of burglaries.

- Men commit $91 \%$ of the offenses against the family.

- Men comprise 94\% of drunk drivers (Carstens 2014:10).

However, South African fathers are not very different from fathers elsewhere. According to Bartlett (2013:1), the problem of father absence escalated from $42 \%$ to $48 \%$ in 2011 . Hence, South Africa is one of the countries in the world with the highest figures of father absence (Richter et al. 2012:2; Richter et al. 2010:360; Freeks 2016:6). It is estimated that 2.13 million children in South Africa is fatherless, and 9 million growup without fathers, a tremendous fatherhood challenge for the country (Dube 2016:2; Frazier 2015). That is the reason why that father absence can be mentioned as one of the main causes that put family life in jeopardy (cf. Ratele et al. 2012). This phenomenon is today on the increase in the South African context, and it generates problems such as broken families, aggressive behavior among children, financial and social problems and poverty (Freeks 2016:2). Notwithstanding, this phenomenon is a desperate cry which is negative because most household families are run by single mothers (Hawkins 2015). Therefore, it seems that South Africa is rapidly becoming a fatherless society with fatherhood in decline (cf. Feni 2016:2). Disheartening, the increasing number of absent fathers on the horizon had become not only a dilemma but a serious debate in South Africa, especially on subjects such as socio-economic, morals, maturation of children, children development, relationships and replacement of fathers.

According to Munroe (2008), the root cause of many socio-economic problems and challenges are the absence of fathers in our world. This is unfortunate for children in many societies today, because these children do not have fathers in their homes, and they do not have the benefit of 
a father to help cultivate within them the honour and respect they need for God, parents, people and society. Hence, the greatest contemporary problems with regard to the maturation of children, is the failure of many fathers to resolve their identity crisis vis-a-vis being a father. This problem is exacerbated by the fact that fathers experience this challenge but would not admit that they do have this problem (Munroe 2008; $c f$. also Castillo 2010).

Tseng and Verklan (2008) indicated that fathers are in crisis due to situational and /or moral issues. Research has shown that where the father is absent, it is reflected in both the development of masculinity in boys and femininity in girls (cf. Perrin et al. 2009). Many children experience a father hunger, a deep, persistent desire for emotional connection with the father (Perrin et al. 2009; Goodsell \& Meldrum 2010; Fagan et al. 2009). Many children are uncertain and confused and deeply feel the need for a father's attachment, presence, and a lifestyle characterized by good values received from their fathers (Freeks \& Lotter 2011; Freeks 2011; Freeks 2007; Algera \& Sink 2002; Carr 2000). Children are in need of a platform of certainty (Ford et al. 2008).

Nevertheless, in many families, there are prolonged periods of separation, which limit the father's opportunity to engage in direct interaction with his children and which reduces the ability of the father to positively influence the children's development (Willerton et al. 2011). Unsuccessful fatherchild-relationships are often caused by absence of fathers (Palkovitz 2007; Perkins 2008). Studies have indicated that boys who grow up without a father can easily become involved in crime and destructive behaviour (Mandara et al. 2005).

Historically, fathers defined their manhood in terms of the various roles they fulfil for their families and for society. At present, these roles are in transition, and there is no longer a solid definition of masculinity. As a result, many fathers believe that they have lost part of themselves, but they generally do not have anything concrete with which to replace it (cf. Munroe 2001). Amidst all the changes in society (of which the role and position of the father is one of the more dramatic changes), children still enjoy a greater advantage when their fathers are involved in their lives (Vogel et al. 2006). 
The value of the father is crucial in terms of the love and attention that he gives to his family and how he leads by example when it comes to values (Williams 2008). Fathers should not only be there to provide material security, as is so often the case. It is important to understand that boys in particular need a role model. Leading by example, especially in terms of values, the boy is able to successfully take up his own role of fatherhood when he matures (Goeke-Morey \& Cummings, 2007). Girls are more balanced when they have a normal relationship with their fathers. Many authors directed an urgent appeal that fathers should embrace their Godgiven identity in order to restore families, societies and communities (Freeks \& Lotter 2009; Williams 2008; Steytler 2007; Munroe 2001). They support the maintenance of the "normal" traditional family, a form that has become increasingly scarce in African countries and in the world as a whole (cf. Zulu \& Sibanda 2005).

Often substitute fathers take up the place of the father. The typical situation in African rural culture is that an older brother replaces the absent or deceased father. This replacement may however create serious problems such as wrong identification and the adoption of wrong values on the part of the children (Olsen 2007). In reality, there are many single-parent families with only a mother figure at the head of the family. These mothers see themselves as more competent child-care providers than the fathers. Such mothers play a key role in determining the father's place in the family and often oversee, correct and criticize fathers' parenting behaviour (Tremblay \& Pierce 2011). Some studies show that the role of the father is ranked second to that of the mother in the family (cf. Ford et al. 2008). According to Martin et al. (2010), many supportive fathers influence child development more as potential buffers against unsupportive mothers.

\section{Research question}

From the above introduction and problem statement, the question arises: How should the father be active and effective in his role in terms of the family?

Questions arising from this main research question are the following:

- What guidelines may be found for active and effective fathering in the Fatherhood Training and Equipping Programme? 
- What insights and personal experiences from fathers may be found for active and effective fathering?

- What does an empirical study reveal about the problem of father absence and fatherlessness where fathers lack responsibility and accountability in terms of fatherhood within the family?

- How can the father be trained and equipped to deal with these problems of father absence and fatherlessness, and to bring about positive change in society?

\section{Purpose of the research}

The purpose was to empirically research the personal experiences of fathers while growing up and to train and equip them to be active and effective in their role as fathers within the family.

\section{Research objectives}

Specific objectives of the research are:

- To investigate what guidelines are to be found on active and effective fathering and the role of the father.

- To research what insights and personal experiences from fathers may be found for active and effective fathering.

- To do a quantitative empirical study on the problems of father absence and fatherlessness in families.

- To train and equip fathers to be active and effective within the family, and to bring about positive change in society.

\section{Central theoretical statement}

The central theoretical statement in this article is that fathers have an active and effective role to play in the family and should be trained and equipped for taking up this role. 


\section{Research methodology}

\subsection{Research design}

In this article, the research is an exploratory design and embedded in using the qualitative approach to investigate the personal experiences of fathers while growing up, and such investigation was necessary, as this has not yet been explored.

\subsection{Research method}

The method of research that the researcher used for data gathering was structuring interviews with fathers (cf. Botma et al. 2010:204-206).

\subsection{Measuring instrument}

The researcher attempted to explore the experiences and feedback of fathers, using structured interviews. Descriptive research is normally used for quantitative research but it can also be used in a qualitative research (Vyhmeister 2008).

\subsection{Participants}

Participants were adult fathers $(\mathrm{N}=14)$ between the ages of $30-65$, living within the different communities in Potchefstroom.

\subsection{Sample}

The researcher attempted to investigate the personal experiences of fathers while growing up, using structured interviews.

\subsubsection{Sampling}

Fathers were selected because they were trained and equipped with the Fatherhood Training and Equipping Programme.

\subsubsection{Sample size}

The fathers for the qualitative research (structured interviews) were 14 in total.

\subsection{Data gathering}

The researcher and FAMSA identified the participants (fathers) from the different communities in the Potchefstroom district and contacted them by 
telephone to arrange with them for an appointment, time and place where structured interviews were going to be conducted. The physical setting where structured interviews were conducted was in the training room of FAMSA. The settings were private, conducive, pleasant and comfortable with little or no distractions (cf. Pinkoane 2005).

For the qualitative research (questions to fathers), five open ended questions were formulated to ensure that similar exploration will be done with all fathers (Botma et al. 2010). The open-ended questions were first evaluated, refined and adjusted by the researcher to determine whether the questions were clear, understandable and appropriate (cf. Botma et al. 2010). The researcher conducted a pilot study with the structured interviews with one participant (father). The data were usable and included in the results.

The questions for fathers were the following:

- Tell me what your opinion is about the role of the father within the family.

- Tell me about your feelings after the presentation on the essence of fatherhood.

- Tell me about your personal experience after the Fatherhood Training and Equipping Programme.

- What do you think should the role of today's father be?

- Write down what you should like to change in your life as a father so that it can have a positive impact on your family.

\subsection{Data analysis}

The qualitative research (structured interviews) were analysed by the researcher, and any raw data were refined into relevant and general sense making information. The data is presented in the results (see point 9).

\subsection{Ethical considerations}

In terms of the ethical considerations, the ethical aspects are there to protect the rights and integrity of the participants and the researcher. The individuals or participants are autonomous, and have the right to selfdetermination and this right should be respected (Burns \& Grove 2005:186). 
FAMSA (Families South Africa) is an NGO (non-government organization) as well as a NPO (non-profit organization) that works on a daily basis with families in society and various communities. FAMSA gets the permission and consent of families before any work, activity, counselling, therapy, training, etc., can be conducted. The intervention, training and equipping of fathers was a joint effort with fathers, the presenter and FAMSA. On the ethical agreement, ${ }^{3}$ both FAMSA and the researcher conducted the intervention and written informed consent was obtained during the initial training and equipping of fathers. Informed consent entails informing the research participants about the overall purpose of the investigation ( $c f$. Kvale \& Brinkmann 2009:70). Furthermore, fathers were fully informed about the voluntary nature of this training and equipping programme, and they had the right to withdraw from the study at any time he felt uncomfortable.

\section{Research and the intervention programme}

\subsection{Research foundation}

The research focussed on the father as mentor and transmitter of values (Freeks 2011). This research was conducted within a pastoral-theological paradigm. Pastoral theology is definable in terms of certain elements: it is Scripture bound, it is practical, it works with empirical reality, focuses on the church and other communities of faith and, as a discipline, is situated in the wider world. It should take note of other relevant subject areas such as psychology, sociology, physiology, social work and even feminism (cf. Lotter 2007). The central theoretical position of the current research is that fathers have an active and effective role as mentors in terms of transmitting values to the family and should in turn be equipped to take up this role (Freeks 2011). The model that the researcher used provided guidelines for equipping the father in his role as mentor. Freeks (2011 cf. also Roest et al. 2009) describes the importance of values for the father as mentor.

There are of course many roles that a father can fulfil apart from being a father to his children, i.e. husband to his wife, a teacher, community

3 Ethical approval and permission to conduct research (Freeks, 2011:114, 121-122) 
leader, spiritual leader and others. In this research, it was important to focus on the father as a positive role model ( $c f$. Freeks 2013; Freeks \& Lotter 2009). It is fundamental that every father should be a positive role model because children look up to their fathers as examples of how to behave. The actions and behaviour of parents play a significant role in the development of a child's personality (Blackthorn 2004). The father however, can be a successful role model only if he adheres to certain values. The father is the ideal role model for his children because his children can most easily learn from his behaviour and attitudes (Freeks 2013; Freeks 2004). The father can also be a role model for other fathers by demonstrating how he helps and supports his children. One of the principal functions of the father is to instil discipline: it is his role to set the limits of behaviour (Dobson \& Bauer 1990). Effective discipline requires not only wisdom, but also patience and persistence (Euvrard 2006; Rens 2005; Mentz \& Wolhuter 2003; Drescher 1988). Discipline is one of the most important aspects requiring attention when training and educating a child; though discipline is concerned with authority and tasks, it also requires responsibility and duty on the part of the child (Pougnet et al. 2011; Mentz \& Wolhuter 2003; Nel \& Steyn 1985).

If the father does not make use of punishment, he actually withholds a potentially effective measure ( $c f$. Faber \& Mazlish 2003). The father should be the one who disciplines, but discipline need not always take the form of punishment. Discipline takes teaching to the next level: the child is not only taught, but also corrected and instructed. This helps to shape the child's character, because discipline becomes training (Munroe 2008). According to Austin (2007), discipline can be meted out in conjunction with affection; the father cares for and loves his children while he disciplines them (cf. also Larney 2009). Where Munroe (2008) sees discipline as teaching and correcting, Henley (1997) refers to discipline as a two-sided coin where the one side is direction and the other correction. Henley (1997) further states that this kind of discipline is actually a form of discipling, in other words making disciples or followers of good behaviour.

In conjunction with the abovementioned, correction and direction thus imply similar outcomes, because to direct a child away from a wrong behaviour is to make the child a good disciple. It ensures that the child is directed away from a wrong path onto a right one. Fathering without good guidance on how to discipline the child will not be successful. A clear 
disciplinary strategy will probably be the most effective way for the father to accomplish what he wants (Christophersen \& Mortweet 2003). The father needs to be an ideal figure in educating and disciplining his children in the fear of the Lord (Freeks 2004; cf. also Prov. 1:9).

The father's physical involvement makes the family strong and trustworthy, and when the challenges of life approach, the family is strong and steadfast. In the context of this article, it is crucial to understand that marriage and family are pulled together through the fundamental and physical presence of the father. The physical presence and involvement of the father is imperative long before his wife is pregnant, and gives birth to their children. His physical role is vital in terms of educating his children, in the sense that he is the primary teacher in the home. His children will, accordingly, be able to perform better at school.

An important responsibility a father should consider in his home is the portrayal of Jesus Christ on earth, and to his family. Conversely, the plan of the devil for that reason is to create a distorted image of the father, however, the father is the one that must ensure that God is worshipped and obeyed within the family. His status should be spiritual because man and spirituality is encountered at the most intimate level, which is known as the family (Bergh 2002).

In order to strengthen the father in his fatherhood task, he must be motivated to cultivate a love for God and His Word. The father is the priest in the house, and must arrange activities such as prayer meetings, house altar, family communion, etc. He must orientate his life to the Bible, and should apply its wisdom in a practical manner to the daily lives of his children because they understand the concept of God the Father, better, if they understand their earthly father (cf. Freeks 2004).

Fatherhood is of great importance because it stems from the Bible. Therefore, in order to solve the fatherhood crisis and the dilemma in which today's fathers find themselves, solutions and advice should be based on a Biblical point of view ( $c f$. Freeks 2016). Relevant questions to ask in this regard are:

- How can true fatherhood be restored?

- How can fathers break this cycle of bad fathering? 
- Can the negative statistics of father absence and fatherlessness, as mentioned above, be reversed by the power of fathers who have been restored to their place in the family, and to their true calling as men?

As researcher on fatherhood, I have to believe that these downward trends can be reversed in order to strengthen lives, families and communities ( $c f$. Munroe 2008:13). The only way, however, that fathers can break this cycle of bad fathering is through Jesus Christ. Only He can breathe new life into the situation of families and only He can break the cycle of bad fathering.

Furthermore, it is fundamental to know that the highest honour God can give a man is to designate him a father (Munroe 2008). That is in fact a man's title, and if God can convey such a title upon the man, then it must be the highest designation and honour a man can have. With regard to fatherhood, it should be the task of the male ( $c f$. Carstens 2014:59-70; O’Donnell 2011:21-33; Munroe 2008:43-56; Munroe 2001:71-98), whether it is fathers with children or fathers without children, or even sterile fathers. However, this task has greater responsibilities. Interestingly, God created the world, heaven, earth, animals, but most importantly, man, the crown of creation with responsibilities ( $c f$. Gn 2:4-7).

Fatherhood consists of several duties, accountabilities and responsibilities, such as communication, rules, managing their children's behaviour, keeping them healthy, educating them, guiding them (physically, socially and emotionally), taking care of them and loving them (Freeks 2011; Blackthorn 2004). These duties, responsibilities and accountabilities are realized in terms of his practical and physical interaction with his children (Coakley, 2006; Freeks 2004).

Young fathers today still need to learn the purpose, principles and functions of true fatherhood (Munroe 2008). These principles are more than just formulae; they are God-given imperatives that lay down laws that govern life.

The father's main duty is to be involved with his children, not only on a practical level, but also affectively (emotively). His involvement helps in the formation and consolidation of the child's general identity, including his/her sexual identity. Such involvement determines all kinds of outcomes such as depression, inappropriate behaviour and adjustments (Cruz et al. 2011; Berg 2002; Freeks \& Lotter 2009). 


\subsection{The aim of the intervention}

The intervention (based on the research of Freeks 2011) which was mentioned and explained earlier was developed with the aim of training and equipping South African fathers. It entailed training and equipping material for the father to fulfil his role as mentor in the family, and to transmit values to his family.

\subsection{The planned intervention and the implementation thereof}

An intervention was planned by FAMSA (Families South Africa) in collaboration with the researcher and his research on fatherhood (cf. Freeks 2011) to address the above-mentioned challenges. As previously indicated, the intervention was mainly based on research about the essence of fatherhood ( $c f$. Freeks 2011). This planning was under discussion for a period of 5 months, and it critically dealt with all the aspects to implement a timely, practical and relevant answer to a problematic issue, i.e. father absence and fatherlessness. The intervention was implemented by launching a fatherhood convention, which entails training and equipping South African fathers to be involved and to be available and better fathers to their families. Fathers, future fathers, young men, married and unmarried men attended the convention mostly out of interest and concern for the above-mentioned problems and challenges in our societies. The convention was held in 2011 where all fathers in Potchefstroom and surrounding communities i.e. Ikageng and Promosa with their different denominations have been invited to attend a presentation with the focus on fatherhood. A group of seventy fathers attended the presentation on that specific day.

\subsection{Training and equipping the father}

After the presentation on the essence of fatherhood, a support group consisting of 14 fathers was established, trained and equipped through a fatherhood-training manual. The material that was used for the training and equipping of fathers was a training manual and a workbook as assessment criteria. The training manual consisted out of 7 practical and relevant sessions namely, the concept of fathering, the father as his selfimage, character and career and the plans of God, the father and labelling and how to overcome it, how fathers should handle disappointments, the father as developer in his family and becoming fully you. After the training 
and equipping programme, the support group of 14 men decided to meet every month to discuss problematic issues, experiences and insights.

\section{Reported findings}

Findings obtained from the fathers who participated in the interviews will be discussed. Richness is provided by verbatim quotes and support from literature in the research to validate the findings. The purpose of literature is to compare the findings with existing literature and to draw conclusions. The following six themes emerged from the interviews with the fathers:

\subsection{The absent father}

Fathers indicated that they themselves had no father figure. They mentioned that the absent father is a disadvantage in homes. They expressed their views in words such as: "if there is no father figure, it has a negative influence on the children"; "the absent father is a disadvantage".

Freeks and Lotter (2009:520-521), Williams (2008:18) and Palkovitz (2007:195) supported the findings by indicating that the absent father causes tremendous pain and suffering in homes. The narratives of respondents in the empirical research of Freeks and Lotter (2009:520) showed that society is in a dilemma because of the absence of fathers in the lives of children. Steytler (2007:36) indicated that the absent father has an undeniable effect on sons, and it causes a poor self-image. Fathers' absence has a direct influence on the social functioning of son's because they become unemployed and uninvolved in the lives of children (Steytler 2007:37-38). Sons experience identification problems and daughters are under severe pressure because of the absent father (Seutter \& Rovers 2004:43-45).

\subsection{Men lost their way}

Fathers felt that men have lost their way, and now they feel inferior towards women. They express their views in words such as: "our men lost their way", "men are feeling inferior towards women because women are earning a bigger salary than their husbands", "some men lost their position in the family", "men lost their knowledge about their role as father".

Bergh (2002:84) supported the findings in his research. He indicated that confusion reigns more in the modern milieu of family life, especially in the 
area of the husband's role in marriage. He also stated that men struggle and are unsure about their role in marriage, and therefore escape their role of fathers. Freeks (2004:55, 95-98) stated in his research that the role of the father is in fact accepted by the local community of Promosa in Potchefstroom as an authoritarian position and worthy according to the Word of God.

\subsection{The importance of God within the family}

Fathers identified God as an important aspect within the family, and He wanted unity from the beginning. Fathers expressed their views in words such as: "God is priority and comes first in everything", "God is an important aspect within the family", the family is important in the eyes of God", "God should always be mentioned in families and society", "families with a strong religious background result from the position of the father figure".

McGraw (2004:10) supports the findings in literature. He indicated that the role of families is the highest, noblest calling from God, and parents should be aware of this standing, deeply committed and proactive role. Munroe (2008:23-31) stated that God created male with a particular purpose in mind. He intended men to be fathers and therefore God designed them to be so. God is important in the lives of a family because the Fatherhood of God is the original image of earthly fatherhood and the origin of human fatherhood is born out of the Fatherhood of God (cf. also Verhoef 2011:14; Steensma 1995:183). In my view, this implies that God should be regarded as "male" ( $c f$. Munroe 2008:30-40). God is the first priority within a family, and $\mathrm{He}$ wills to perpetuate the human race until the end of time (Bergh 2002:47).

\subsection{Fathers should depend on God}

Fathers mentioned that their role as fathers was a gift through the Grace of God. They expressed their views in words such as: "the Heavenly Father is the perfect Father for us as fathers", "earthly fathers should reflect the Heavenly Father in their fathering role, and "It was through His Fatherly Grace that I play a positive role in the lives of my children".

The findings are supported by Crow (2008:89-93) who indicated in his research that Jesus Christ is the good and perfect example who gave His 
life into the hands of His Father will. Hence, the role of the earthly father should be the same in the family where the mother and children should put their lives and trust in the hands of the father who received his power and strength from the Heavenly Father ( $c f$. Joh. 18:11, Matt 7:7-11). Bergh (2002:119) mentioned in his research that parents are dependent on and responsible to God.

\subsection{The role of the father is crucial}

Fathers indicated that the role of the father is crucial in the lives of their children, especially with teenagers when they are faced with relationship problems and life's challenges. However, in this article, it should also be kept in mind that the role of mothers is indispensable and fundamental in terms of their task and contribution towards the lives of children. Nevertheless, fathers expressed their views in words such as: "dad is the boss in the house", "he is the captain of the ship, but today we have a ship without a captain", "the role of the father is vital, he must be there".

Austin (2007:4) who mentioned in his research that the involvement of the father is crucial in the upbringing of children supports the findings. Bergh (2002:82 \& 120) indicated in his study that the role of the father is fundamental in the lives of children because God put His seal on the man to take up his role as father (cf. also 1 Th 2:11-12).

\subsection{Fathers should be role models}

Fathers indicated that the father should be a role model to his family. They expressed their views in words such as: "the father is the role model and children don't have anyone else to admire as a role model", "children need to know that we as fathers are their role models".

Stephens (2007; cf. also Bergh 2002:168; Munroe 2001:201-203) supported the findings by indicated that the father is the best role model for his children because children learn through the behaviour and attitude of their parents. Barker (2008:1-3) indicated in his research that the father as role model helps in the development of children. 


\section{Conclusion}

It is fundamental to take into consideration that the findings form an integral part of the central theoretical argument in this article. The overall view of fathers was the idea that the father as leader and authority figure in the home should govern his family from the Bible because his role was neglected and should be restored according to Biblical principles. This view was the whole purpose and vision of the intervention and the Fatherhood Training and Equipping Programme.

\section{Shortcomings of the intervention and the training and equipping of fathers}

From the intervention and the training and equipping of fathers, the following shortcomings were identified:

- A lack of effort to spur on and follow-up on all fathers to attend the training and equipping programme was a serious problem for both the researcher (presenter) and FAMSA, because after the presentation on the essence of fatherhood to 70 fathers, it was disappointing to see that only 14 fathers attended the training and equipping programme.

- A lack of support from the communities, denominations and leaders where these fathers function were evident because during discussion sessions some fathers complained about the negative remarks and statements made about the importance of fatherhood.

- The venue where the training and equipping took place caused ample frustrations and difficulties for fathers, and resulted many times in poor attendance.

- Inadequate follow-up from fathers to their immediate smaller groups in the communities as well as progress reports not submitted caused disharmony with Social Development who funded the training and equipping programme for fathers.

\section{Recommendations}

The fatherhood intervention programme was implemented, mainly due to collaboration with FAMSA, as well as the passionate presentation of the programme and the thorough preparation beforehand. It is very important 
to have permission to access the community before any programme, intervention, workshop or research can be done in communities. It is furthermore crucial to have and to build networks and relations with different stakeholders, social development, authority figures, leaders and denominations as well as local government concerning the community.

\section{Final Conclusion}

The father figure in the family has to adopt and implement a strategy of supportiveness and physical involvement, all of which is meant to ensure healthy relations with the family. Using this strategy, the father will have sound relations with his family. Furthermore, fathers should know that it is important to recover and to restore the original meaning of what it is to be a man and father, and as such, to represent the image of God in a world hungry and in desperate need of virtuous and involved fathers. In addition, fathers have the ability and willpower to make a difference and to have an impact on the family because they lay the foundation on which future relationships are built. Thus, a change for the better in terms of the greater involvement of fathers will also portray the true meaning of family to society, as God intended it to be.

\section{Bibliography}

Algera, HF \& Sink, CA 2002. Another look at character education in Christian schools. Journal of Research on Christian Education, 11(2):161-181.

Austin, MW 2007. Conceptions of parenthood: Ethics and the family. Hampshire, UK: Ashgate.

Barker, CJ 2008. James Bernard: fatherhood means leadership and commitment. New York Amsterdam news, 99(25):5, Dec.

Bartlett, E 2013. Die impak van afwesige vaders op adolessente meisies se psigososiale welstand. Hons skripsie, Departement van Maatskaplike Werk, Noordwes-Universiteit, Potchefstroomkampus.

Bergh, SJ 2002. Gesinsbediening as 'n geïntegreerde deel van die opbou van die gemeente, Doctoral thesis, University of Free State, Bloemfontein, South Africa. 
Blackthorn, S 2004. The parent's guide to parenting. Indianapolis, IN:Wiley.

Botma, Y., Greeff, M., Mulaudzi, M \& Wright, SCD 2010. Research in health sciences. Cape Town: Clyson Printers.

Burns, N. \& Grove, S. 2005. The practice of nursing research, conduct, critique and utilization. $5^{\text {th }}$ ed. Missouri: Elsevier Saunders.

Carr, D 2000. Moral formation, cultural attachment or social control: What's the point of values education? Educational Theory, 50(1):1-10.

Carstens, C 2014. The world needs a father: a trainers' guide. Cape Town: Paarl Media Printers.

Castillo, JT 2010. The relationship between non-resident fathers' social networks and social capital and the establishment of paternity. Child Adolescent Social Work Journal, 27:193-211.

Christopherson, ER \& Morweet, SL 2003. Parenting that works: Building skills that last a lifetime. Washington, DC: APA Life Tools.

Coakley, J 2006. The good father: Parental expectations and youth sports. Leisure Studies, 25(2):153-163.

Crow, DM 2008. Multiplying Jesus mentors: designing a reproducible mentoring system: a case study. Missiology, 36(1):87-109, Jan.

Cruz, RA, King, KM, Widaman, KF, Leu, J, Cause, AM \& Conger, RD 2011. Cultural influences on positive father involvement in two-parent Mexican-origin families. Journal of Family Psychology, 25(5)731-740.

Del Russo, JM 2009. Emotionally absent fathers and their adult daughters' relationship with men. Unpublished doctoral dissertation. Philadelphia, United States: Chestnut Hill College.

Dobson, J \& Bauer, GL 1990. Children at risk. Dallas, TX: Word Publishing.

Drescher, JM 1988. Seven things children need: Significance, security, acceptance, love, praise, discipline, and God. Pennsylvania, PA: Herald Press.

Dube, D 2016. 2.13 million kids in SA fatherless. The New Age, 2, 5 Jul. 
Euvrard, G 2006. The values manifesto project. Educational Leadership, 63(8):1-6.

Faber, A \& Mazlish, E 2003. How to talk so kids can learn at home and in school? Piccadilly Press, London, UK.

Fagan, J, Palkovitz, R, Roy, K \& Farrie, D 2009. Pathways to paternal engagement: Longitudinal effects of risk and resilience on nonresident fathers. Developmental Psychology, 45(5):1389-1405.

Fathers for Life 2013. Children of divorce and separation-statistics: consequences of father absence, Census, viewed 19 June 2014, from http://fathersforlife.org/ divorce/chlddiv.htm

Feni, L 2016. Forum raises concern over fatherless society. Daily Dispatch: 2, 21 Mar.

Ford, JJ, Nalbone, DP, Wetchler, JL \& Sutton, PM 2008. Fatherhood: How differentiation and identity status affect attachment to children. American Journal of Family Therapy, 36(4):284-299.

Frazier, T 2015. The result of fatherlessness in South Africa. http://www. tumifrazier.com/fatherlessness-in-south-africa/ Date of access: 28 Nov. 2016.

Freeks, FE \& Lotter, GA 2009. 'n Praktiese-teologiese ondersoek na die uitwerking van afwesige vaders: 'n Verkennende kwalitatiewe ondersoek in die Promosa-gemeenskap. Koers, 74(3):519-534.

Freeks, FE \& Lotter, GA 2011. Waardes en die noodsaak van 'n karakteropvoedingsprogram binne kollegeverband in die Noordwes Provinsie: Verkenning en voorlopige voorstelle, Koers, 76(3):577-598.

Freeks, FE 2004. Die rol van die ontbrekende vaderfiguur in die SuidAfrikaanse konteks. 'n Prakties-teologiese studie. MA Verhandeling, Dept. van Teologie, PU vir CHO, Potchefstroom, Suid-Afrika.

Freeks, FE 2007. 'n Karakterbouprogram vir verdere onderwys en opleidingskolleges, PhD tesis, Dept. van Opvoedkunde, NoordwesUniversiteit, Potchefstroom, Suid-Afrika.

Freeks, FE 2008. Manual for course facilitators: LIFEPLAN`. Africa Unit for Trans-disciplinary Health Research (AUTHeR), North-West University, Potchefstroom, South Africa. 
Freeks, FE 2011. The role of the father as mentor in the transmission of values: A pastoral-theological study, $\mathrm{PhD}$ thesis, Dept. of Theology, North-West University, Potchefstroom, South Africa.

Freeks, FE 2013. Dad is destiny: the man God created to be, Ivyline Technologies, Potchefstroom.

Freeks, FE 2016. Die noodsaak van Skrifgefundeerde vaderskap as antwoord op die voortslepende probleem van vaderafwesigheid in Suid-Afrika. Tydskrif vir Christelike Wetenskap, 52(1\&2):1-27.

Goeke-Morey, MC \& Cummings, EM 2007. Impact of father involvement: A closer look at indirect effects models involving marriage and child adjustment. Applied Development Science, 11(4):221-225.

Goodsell, TL \& Meldrum, JT 2010. Nurturing fathers: A qualitative examination of child- father attachment. Early Child Development and Care, 180(1-2):249-262.

Hawkins, C 2015. Most SA households run by single moms. SA breaking news, 3 Sep. http://www.sabreakingnews.co.za/2015/09/03/most-sa-households-runby-single-moms/ [Accessed: 7 Dec. 2016]

Henley, K 1997. Child-sensitive teaching: Helping children grow a living faith in a loving God, Zondervan, Nashville, TN.

Krohn, FB \& Bogan, Z 2001. The effects absent fathers have on female development and college attendance. College Student Journal, 35(4):598-608.

Larney, T 2009. Die gesin as primêre geloofseenheid in 'n postmoderne konteks: 'n Pastorale studie, $\mathrm{PhD}$ tesis, Noordwes-Universiteit, Potchefstroom, Suid-Afrika.

Le Roux, A 2007. 'n Kruiskulturele ondersoek na studente se houdings teenoor hul vaders. Tydskrif vir Christelike Wetenskap, 3: 91-106.

Lotter, GA 2007. Pastorale Teologie: Voëlvlug en (voorlopige) landing. Wetenskaplike bydraes, Reeks H: Intreerede nr. 185, Noordwes Universiteit, Potchefstroom, Suid Afrika.

Mandara, J, Murray, CB \& Joyner, TN 2005. The impact of fathers' absence on African American adolescents' gender role development. Sex Roles, 53(3/4):207-220. 
Martin, A, Ryan, RM \& Brooks-Gunn, J 2010. When fathers' supportiveness matters most: Maternal and paternal parenting and children's school readiness. Journal of Family Psychology, 24(2):145155 .

McGraw, P 2004. Family first: your step-by-step plan for creating a phenomenal family. New York, Free Press.

Mentz, PJ \& Wolhuter, CC 2003. 'n Perspektief op die voorkoms van discipline probleme in Afrikaanse skole. Koers, 68(4):391-412.

Munroe, M 2001. Understanding the purpose and power of men: A book for men and the women who love them, Whitaker House, New Kensington, PA.

Munroe, M 2008. The fatherhood principle: Priority, position, and the role of the male, Whitaker House, New Kensington, PA.

Nel, WMJ \& Steyn, GH 1985. Kinders grootmaak! (Raising children!), HAUM Opvoedkundige Uitgewery, Pretoria, South Africa.

O'Donnell, MA 2011. What a son needs from his dad: how a man prepares his sons for life, Minnesota, Bethany House Publishers.

Olsen, S 2007. Daddy's come home: Evangelicalism, fatherhood and lessons for boys in late nineteenth-century Britain. Fathering, 5(3):174-196.

Palkovitz, R 2007. Challenges to modelling dynamics in developing a developmental understanding of father-child relationships. Applied Developmental Science, 11(4):190-195.

Perkins, RJM 2008. Father-daughter relationship inventory (MP-FDI): Construction, reliability, validity, and implications for counselling and research. Measurement and Evaluation in Counselling and Development, 41:130-151.

Perrin, PB, Baker, JO, Romelus, AM, Jones, KD \& Heesacker, M 2009. Development validation, and confirmatory factor analysis of the father hunger scale. Psychology of Men \& Masculinity, 10(4):314-327.

Pinkoane, MG 2005. Incorporation of traditional healers into the national health care delivery system, Doctoral thesis, Dept. of Nursing, NorthWest University, Potchefstroom, South Africa. 
Pougnet, E, Serbin, LA, Stack, DM \& Schwartzman, AE 2011. Fathers' influence on children's cognitive and behavioural functioning: A longitudinal study of Canadian families. Canadian Journal of Behavioural Science, 43(3):173-182.

Ratele, K, Shefer, T \& Clowes, L 2012. Talking South African fathers: a critical examination of men's constructions and experiences of fatherhood and fatherlessness. South African Journal of Psychology, 42(4):553-563.

Rens, JA 2005. Riglyne vir waardeopvoeding in Suid-Afrikaanse skole. PhD tesis, Dept. van Opvoedkunde, Noordwes-Universiteit, Potchefstroom, Suid-Afrika.

Richter, L, Chikovore, J \& Makusha, T 2010. The status of fatherhood and fathering in South Africa. Childhood education, 86(6):360-365.

Richter, L, Desmond, C, Hosegood, V, Madhavan, S, Makiwane, M, Makusha, T, Morrel, R \& Swartz, S 2012. Fathers and other men in the lives of children and families. Paper presented at the "Towards Carnegie III" conference at the University of Cape Town on 3-7 September. [Online] Available: https://www.google.com/url?sa=t\&rct=j\&q=\&e $\mathrm{src}=s \&$ source $=$ web\& $\mathrm{cd}=1 \& \mathrm{ved}=0$ ahUKEwjlisjF3ITQAhVBD8AKHaQuB9gQFggfMAA\&url= http\%3A\%2F\%2Fcarnegie3.org.za\%2Fdocs\%2Fpapers\%2F231_Richter_Fathers\%2520a nd\%2520other\%2520men\%2520in\%2520the\%2520lives\%2520of\%2520children\%2520 and\%2520families.pdf\&usg=AF0jCNFMj00mFah41LBY_KIKx18b4RFKw\&sig2=V04ZhCrp6uCCOD1WuuJjg\&cad=rja [Accessed: 31 Oct. 2016]

R \& Swartz, S 2012. Fathers and other men in the lives of children and families. Paper presented at the "Towards Carnegie III" conference at the University of Cape Town on 3-7 Sept. https://www.google.com/url? $\mathrm{sa}=\mathrm{t} \& \mathrm{rct}=\mathrm{j} \& \mathrm{q}=\& \mathrm{esr}=\mathrm{s} \&$ source $=$ web\& $\mathrm{cd}=1 \& \mathrm{ved}=0$ ahUKEwjlisjF3ITQAhVBD8AKHaQ uB9gQFggfMAA\&url=http\%3A\%2F\%2Fcarnegie3.org.za\%2Fdocs\%2Fpapers\%2F231_ Richter_Fathers\%2520and\%2520other\%2520men\%2520in\%2520the\%2520lives\%25 20of\%2520children\%2520and\%2520families.pdf\&usg=AFQjCNFMjQ0mFah41LBY_ KIKx18b4RFKw\&sig2=V04Zh-Crp6uCCOD1WuuJjg\&cad=rja [Accessed: 31 Oct. 2016]

Roest, AMC, Dubas, JS \& Gerris, JRM 2009. Value transmissions between fathers, mothers, and adolescent and emerging adult children: The role of the family climate. Journal of Family Psychology, 23(2):146-155. 
Seutter, RA, \& Rovers, M 2004. Emotionally absent fathers: furthering the understanding of homosexuality. Journal of psychology and theology, 32(1):43-49.

StatsSA (Statistics South Africa) 2011. General Household Survey 2010, Statistical release PO318, June 2010, viewed 30 September 2014, from http://www.statssa.gov.za/publications/P0318/P0318June2010.pdf.

Steensma, DJ 1995. Ouders en kinderen: een theologisch-ethische bezinning. Zoetermeer: Boekencentrum.

Stephens, K 2007. Parents are powerful role models for children. https:// www.google.com/url?sa=t\&rct=j\&q=\&esr $=$ =s\&source=web\&cd=1\&ved=0ahUKEwiG uoTB2K_SAhWqCSAKHVQJCH4QFggeMAA\&url=http\%3A\%2F\%2Fwww.easternflorida. edu\%2Fcommunity-resources\%2Fchild-development-centers\%2Fparent-resourcelibrary\%2Fdocuments\%2Fparents-powerful-role-models.pdf\&usg=AFQjCNFpp4Ct73zZyT RrNcdp2cNe4YigXw\&cad=rja [Accessed: 27 Feb. 2017]

Steytler, JPD 2007. Mentorskap in die maatskaplike funksionering van die seun in sy laat-middelkinderjare, Verhandeling, NoordwesUniversiteit, Potchefstroom, Suid-Afrika.

Thorne, S Interpretive description. 2008. Walnut Creek, California: Left Coast Press.

Tremblay, S \& Pierce, T 2011. Perceptions of fatherhood: Longitudinal reciprocal associations within the couple. Canadian Journal of Behavioural Science, 43(2):99-110.

Tseng, YS \& Verklan, MT 2008. Fathers in situational crisis: A comparison of Asian and Western cultures. Nursing \& Health Sciences, 10(3):229-240.

Verhoef, GC 2011. God is ons Vader. Die Kerkblad, February 14.

Vhymeister, NJ 2008. Quality research papers: for students of religion and theology. $2^{\text {nd }}$ Ed. Michigan: Zondervan Grand Rapids.

Vogel, CA, Bradley, RH, Raikes, HH, Boller, K \& Shears, JK 2006. Relation between father connectedness and child outcomes. Parenting: Science \& Practice, 6(2/3):189-209. 
Willerton, E, Schwarz, RL, Wadsworth, SMM \& Oglesby, MS 2011. Military fathers' perspectives on involvement. Journal of Family Psychology, 25(4):521-530.

Williams, A 2008. We badly need good fathers. Human Events, 64(21):18.

Zulu, EM \& Sibanda, A 2005. Racial differences in household structure: The Demography of South Africa, New York, M.E. Sharpe. 